\title{
Pengembangan Panduan Sinema Edukasi dengan Model Blended Learning untuk Menurunkan Prokrastinasi Akademik Siswa Sekolah Menengah Atas
}

\author{
(Development of Educational Cinema Guide with Blended Learning Model to \\ Reduce High School Students' Academic Procrastination)
}

\author{
Wisnu Cahya Dinata*, Diniy Hidayatur Rahman, Henny Indreswari \\ ${ }^{1}$ Universitas Negeri Malang, Jl. Semarang No. 5 Malang, Jawa Timur, Indonesia \\ 2Institut Agama Islam Negeri Kerinci, Jl. Pelita IV, Kerinci, Jambi, Indonesia \\ *Penulis korespondensi, Surel: wisnu.cahya.1701116@student.um.ac.id
}

Paper received: 11-Jan-2022; revised: 3-Feb-2022; accepted: 9-Feb-2022

\begin{abstract}
This study aims to produce an educational cinema guide with a blended learning model to reduce academic procrastination of high school students who meet the acceptance criteria, including accuracy, usefulness, attractiveness, and convenience through material expert tests, media expert tests, and prospective users tests. This study adapts the development research design of Borg and Gall. The data generated are quantitative data and descriptive data. Quantitative data analysis used the inter-rater agreement model technique from Gregory. Descriptive data analysis was carried out by collecting criticism and input from experts and potential users, then used as material for product revision. The results of this product data analysis got a validation index from two material experts with a score of 1.00, two media experts got a score of 1.00, and two potential users got a score of 1.00, which means that all tests carried out have a very high validation index and fulfills the elements of acceptability, namely aspects of accuracy, usefulness, attractiveness, and convenience. This result means that the developed guide has been accepted and is suitable for school counselors to reduce the level of academic procrastination of high school students.
\end{abstract}

Keywords: academic procrastination; educational cinema; blended learning

\begin{abstract}
Abstrak
Penelitian ini bertujuan untuk menghasilkan panduan sinema edukasi dengan model blended learning untuk mengurangi prokrastinasi akademik siswa SMA yang memenuhi kriteria keberterimaan meliputi: ketepatan, kegunaan, kemenarikan, dan kemudahan melalui uji ahli materi, uji ahli media dan uji calon pengguna. Penelitian ini mengadaptasi desain penelitian pengembangan dari Borg dan Gall. Data yang dihasilkan adalah data kuantitatif dan data deskriptif. Analisis data kuantitatif menggunakan teknik inter-rater agreement model dari Gregory. Analisis data deskriptif dilakukan dengan mengumpulkan data berupa kritik dan masukan dari para ahli dan calon pengguna yang kemudian dijadikan sebagai bahan revisi produk. Hasil analisis data produk ini mendapatkan indek validasi dari dua ahli materi dengan skor 1,00, dua ahli media mendapatkan skor 1,00, dan dua calon pengguna mendapatkan skor 1,00, yang artinya dari semua uji yang dilakukan memiliki indeks validasi yang sangat tinggi dan sangat memenuhi unsur keberterimaan yakni aspek ketepatan, kegunaan, kemenarikan, dan kemudahan. Hal tersebut berarti panduan yang dikembangkan telah diterima dan layak digunakan konselor sekolah untuk mengurangi tingkat prokrastinasi akademik siswa SMA.
\end{abstract}

Kata kunci: prokrastinasi akademik; sinema edukasi; blended learning 


\section{Pendahuluan}

Prokrastinasi akademik (menunda tugas) adalah permasalahan yang sangat banyak terjadi di sekolah saat ini khususnya dilakukan oleh para siswa (Abdollahi, Maleki Farab, Panahipour, \& Allen, 2020; Guo, Yin, Wang, Nie, \& Wang, 2019; Hen \& Goroshit, 2020). Hal ini terjadi karena siswa yang lebih memilih untuk melakukan hal yang dianggap lebih menyenangkan dari pada menyelesaikan tugas dari sekolah. Misalnya saja melakukan kegiatan bermain game di handphone atau sekedar bermain sosial media daripada mengerjakan tugas sekolah. Sejalan dengan hasil pembicaraan peneliti dengan beberapa siswa yang mengaku lebih memilih bermain game dan sosial media dari pada menyelesaikan tugas dari sekolah. Namun, beberapa siswa ini mengaku bahwa untuk mengerjakan tugas lebih sering dilakukan pada saat mendekati deadline pengumpulan tugas dan waktu luang lainnya dilakukan untuk bermain handphone dan cenderung mengerjakan secara tergesa-gesa. Hal ini menjadikan siswa terbiasa dengan kegiatan prokrastinasi dan cenderung mendapatkan nilai yang kurang maksimal pada mata pelajaran di sekolah.

Prokrastinasi akademik lazim disebut dengan penundaan kegiatan dalam bidang akademik dan sering sekali dilakukan oleh para siswa sekolah khususnya di Indonesia (Munawaroh, Alhadi, \& Saputra, 2017; Utaminingsih \& Setyabudi, 2012). Prokrastinasi akademik dapat terjadi karena faktor internal dan faktor eksternal (Ghufron \& Suminta, 2010). Faktor dari dalam adalah faktor - faktor yang terdapat dalam diri individu yang memengaruhi prokrastinasi. Faktor dari dalam meliputi kondisi psikologis dan kondisi fisik dari individu. Faktor dari luar meliputi kondisi lingkungan maupun faktor dari gaya asuh orang tua. Candra, Wibowo, dan Setyowani (2014) menyebutkan bahwa faktor yang paling utama penyebab prokrastinasi akademik siswa SMA faktor dari dalam, yaitu kondisi fisik (69\%), kondisi psikologis (73\%). Kemudian faktor dari luar adalah lingkungan sekolah (67\%), kondisi keluarga (75\%).

Prokrastinasi akademik memiliki korelasi dengan penurunan prestasi belajar siswa, variabel tersebut cukup dominan memengaruhi prestasi belajar (Ramadhan \& Winata, 2016). Selain itu penundaan tugas yang dilakukan terus menerus akan memberikan efek negatif kepada siswa dalam menyelesaikan tugas antara lain, kesejahteraan subjektif siswa, stres, dan penyesalan yang akan dialami (Steel \& Klingsieck, 2015). Prokrastinasi akademik dapat mengganggu proses belajar dan prestasi siswa yang artinya siswa di sekolah dapat mengalami kegagalan dalam proses mencapai perkembangan yang optimal dalam bidang akademik.

Hasil wawancara dengan salah satu konselor di sekolah SMA Negeri 7 Malang, peserta didik melakukan prokrastinasi akademik seperti terlambat mengumpulkan tugas hingga tidak mengerjakan tugas. Hal ini diperkuat dengan wawancara dengan salah satu peserta didik SMA Negeri 7 Malang yang datang ke sekolah hanya untuk konfirmasi kesalahan input tugas, hal ini dapat terjadi karena peserta didik tersebut mengerjakan tugas secara tergesa-gesa. Tentunya dari fenomena yang ditemukan ini sangat berdampak negatif terhadap perkembangan peserta didik. Dari wawancara bersama konselor SMA Negeri 7 Malang peneliti juga mendapatkan informasi berupa alat atau layanan yang digunakan untuk intervensi permasalahan prokrastinasi akademik siswa, konselor menggunakan layanan konseling dengan memanggil siswa melalui guru mata pelajaran. Hal ini kurang efektif dikarenakan membutuhkan waktu yang banyak untuk menyelesaikan masalah prokrastinasi akademik siswa sedangkan siswa banyak yang melakukan prokrastinasi. Sekolah membutuhkan layanan yang lebih efektif untuk menurunkan tingkat prokrastinasi akademik yang terjadi di sekolah. Hal ini yang menjadikan 
peneliti ingin mengembangkan layanan yang cocok dengan kebutuhan sekolah. Maka dari itu, diperlukan upaya menurunkan perilaku prokrastinasi akademik dengan cara peneliti mengembangkan layanan bimbingan kelompok dengan menggunakan model sinema edukasi yang mana sinema edukasi ini efektif untuk mengurangi tingkat prokrastinasi akademik di sekolah.

Sinema edukasi dapat meningkatkan efikasi diri (Ragil, Ariyanto, Ratnawati, Ningsih, \& Valdino, 2019). Efikasi diri adalah keyakinan untuk keberhasilan terhadap tugas-tugas yang dapat menunjang siswa mampu menyelesaikan tugas-tugasnya dengan tepat waktu. Sejalan dengan penelitian yang dilakukan oleh Puspita \& Fatchurahman (2018) menyatakan bahwa model layanan penguasaan konten dengan teknik sinema edukasi efektif dapat mengurangi perilaku prokrastinasi akademik peserta didik. Yuslia, Sofah, dan Harlina (2020) menyatakan bahwa layanan bimbingan menggunakan media film pendek dapat menurunkan prokrastinasi akademik siswa. Dari beberapa penelitian tersebut diketahui bahwa sinema edukasi efektif untuk menurunkan prokrastinasi akademik. Sehingga peneliti ingin mengembangkan sinema edukasi sebagai layanan yang dapat menurunkan prokrastinasi akademik.

Adapun penelitian pengembangan produk sejenis untuk menurunkan prokrastinasi akademik telah beberapa kali dilakukan (Lukitasari, 2017; Yuniarisla, 2018). Beberapa pengembangan untuk menurunkan prokrastinasi akademik siswa tersebut mendapatkan hasil layak dan mendapatkan hasil penurunan prokrastinasi akademik yang signifikan dari siswa setelah diberi layanan berupa pengembangan produk tersebut. Tetapi disisi lain, beberapa pengembangan produk tersebut dirasa kurang efektif dilaksanakan pada saat ini, yang mana metode pelatihan manajemen waktu akan membutuhkan banyak waktu dan jika dilihat dari media komik saat ini kurang diminati oleh para siswa SMA. Sehingga dalam hal ini peneliti ingin menggunakan layanan bimbingan untuk menurunkan perilaku prokrastinasi akademik, bimbingan yang digunakan berupa bimbingan kelompok dengan menggunakan metode sinema edukasi.

Dari uraian ada paragraf sebelumnya dapat diketahui bahwa sinema edukasi efektif dan lebih menarik perhatian siswa. Tetapi peneliti mempertimbangkan lagi waktu yang dibutuhkan jika melaksanakan tatap muka secara penuh akan membutuhkan waktu yang banyak. Maka peneliti ingin memodifikasi bimbingan yang memungkinkan untuk dilaksanakan dengan kondisi saat ini tanpa harus menghilangkan makna dari bimbingan sendiri yang mana bimbingan membutuhkan interaksi antara konselor dengan siswa. Adapun layanan bimbingan yang dapat dilaksanakan dan cukup efektif untuk dilaksanakan pada kondisi saat ini serta tidak menghilangkan makna dari bimbingan itu sendiri, bimbingan yang dimaksud yaitu bimbingan secara campuran (blended learning).

Blended learning adalah sebuah model pembelajaran yang menggabungkan pembelajaran luring dengan pembelajaran daring (Bielawski \& Metcalf, 2003). Blended learning merupakan konsep baru dalam pembelajaran dimana penyampaian materi dapat dilakukan di kelas maupun daring. Penggabungan yang dilakukan secara baik antara pembelajaran luring dimana pengajar dan siswa bertemu langsung dan melalui pembelajaran daring yang bisa diakses kapanpun sehingga lebih efisien dilakukan.

Pembelajaran secara blended ini di cukup efektif untuk dilaksanakan (Sjukur, 2012). Adapun penelitian sebelumnya yang dilakukan oleh Febriani \& Erfantinni (2020) menyatakan bahwa pembelajaran campuran dapat menurunkan tingkat prokrastinasi akademik. Sehingga 
dapat diketahui dari beberapa penelitian sebelumnya bahwa blended learning dapat dilakukan dan efektif untuk dilaksanakan dalam melakukan layanan bimbingan di sekolah.

Berangkat dari uraian diatas peneliti ingin mengembangkan sebuah panduan sinema edukasi dengan model blended learning untuk menurunkan prokrastinasi akademik siswa SMA Negeri 7 Malang. Pemilihan tempat penelitian ini didasari dengan kebutuhan sekolah mengenai layanan baru yang lebih efektif dan efisien dilakukan untuk menurunkan prokrastinasi akademik siswa. Panduan sinema edukasi dengan model blended learning diharapkan dapat menjadi panduan yang dapat membantu mempermudah konselor dalam memberikan pelayanan sebagai upaya mengurangi tingkat prokrastinasi akademik siswa SMA Negeri 7 Malang.

\section{Metode}

Penelitian ini menggunakan model pengembangan dari Borg dan Gall (1983) telah dimodifikasi berdasarkan situasi dan kondisi sehingga menjadi: (1) penelitian dan pengumpulan data. Peneliti mengumpulkan serta mengkaji data awal yang dibutuhkan berkaitan dengan prokrastinasi akademik. Dalam penelitian ini peneliti juga melaksanakan wawancara dengan konselor untuk mendapatkan data awal yang berkaitan dengan prokrastinasi akademik siswa SMA Negeri 7 Malang; (2) perencanaan yang mana pada tahap ini peneliti mengembangkan segala kebutuhan yang diperlukan dalam melaksanakan penelitian yang didasarkan dari hasil pengumpulan data awal; (3) pengembangan draf produk dilaksanakan untuk mengetahui gambaran awal produk dengan tujuan dapat lebih memahami masalahmasalah dari rancangan panduan serta dapat menghasilkan pengembangan panduan yang optimal; (4) tahap uji ahli \& revisi produk adalah melakukan uji produk kepada para ahli yang terdiri dari dua ahli materi dan dua ahli media; kemudian merevisi berdasarkan hasil uji, selanjutnya melakukan uji calon pengguna yang terdiri dari dua konselor; (5) revisi produk dilakukan setelah mendapatkan hasil uji calon pengguna.

Data yang dihasilkan dari penelitian ini berupa data kuantitatif dan data deskriptif. Analisis data kuantitatif menggunakan teknik analisis inter-rater agreement model. Teknik analisis inter-rater agreement model digunakan untuk menganalisis data angka berupa skor yang diperoleh dari hasil uji produk yang diberikan oleh ahli materi, ahli media, dan calon pengguna dengan masing-masing 2 orang ahli (Gregory, 2011). Sedangkan data deskriptif yaitu data berupa kritik, saran, dan masukan akan dianalisis dan dideskripsikan guna menarik kesimpulan, sehingga akan memberikan gambaran yang jelas mengenai aspek yang dinilai pada produk buku sinema edukasi dengan model blended learning. Data tersebut juga dijadikan sebagai bahan revisi dalam penyempurnaan produk akhir.

\section{Hasil dan Pembahasan}

\subsection{Hasil}

Penelitian ini menghasilkan produk berupa buku panduan untuk konselor di sekolah. Panduan ini telah disusun berdasarkan kajian literatur dan tersaji berupa buku panduan. Secara umum buku panduan sinema edukasi dengan model blended learning terdiri dari lima bagian pokok, yaitu: (1) Pendahuluan; (2) Wawasan Konsep; (3) Petunjuk Pelaksanaan Layanan; (4) Prosedur Pelaksanaan; (5) Media Film. Produk yang dikembangkan sedemikian rupa ini telah melalui tahap uji ahli materi, uji media, serta uji calon pengguna yang menghasilkan data kuantitatif berupa skor dari ahli dan calon pengguna yang dihitung 
menggunakan inter-rater agreement model serta data deskriptif berupa kritik dan masukan dari ahli dan calon pengguna yang digunakan sebagai bahan revisi produk.

Pada uji ahli materi, media dan calon pengguna yang masing-masing dilakukan oleh dua ahli dan dua calon pengguna. Pada uji ahli dan calon pengguna produk ini mendapatkan hasil penilaian melalui instrumen keberterimaan yang dikembangkan berdasarkan aspek ketepatan, kegunaan, kemenarikan, dan kemudahan. Hasil penilaian dari ahli materi, ahli media dan calon pengguna dijabarkan dalam tabel 1.

\section{Tabel 1. Hasil Uji Produk}

\begin{tabular}{lccc}
\hline \multicolumn{1}{c}{ Uji Produk } & Skor & Kategori & Klasifikasi Validasi \\
\hline Uji Ahli materi & 1,00 & D & Sangat tinggi \\
Uji Ahli media & 1,00 & D & Sangat tinggi \\
Uji calon pengguna & 1,00 & D & Sangat tinggi \\
\hline
\end{tabular}

Interpretasi penilaian ahli materi, ahli media dan calon pengguna dari aspek ketepatan, kegunaan, kemenarikan, dan kemudahan pada panduan ini mendapatkan skor 1,00 yang berarti memiliki validitas yang sangat tinggi. Berdasarkan hasil dari uji yang telah diperoleh maka panduan ini layak untuk digunakan sebagai layanan bimbingan dan konseling dalam upaya mengurangi tingkat prokrastinasi akademik siswa SMA. Keberterimaan dan kelayakan produk ini dapat tercapai dengan memperhatikan data deskriptif yang didapatkan dari kritik dan masukan ahli materi, ahli media, dan calon pengguna sebagai bahan revisi produk.

\subsection{Pembahasan}

Produk buku panduan yang dikembangkan sedemikian rupa menghasilkan data uji ahli materi dengan hasil "sangat layak" yang didapatkan dari dua ahli materi. Hasil uji ahli media yang didapatkan dari dua ahli media memenuhi keberterimaan produk dengan kategori "sangat layak". Hasil uji calon pengguna yang dilakukan oleh dua konselor dengan keberterimaan yang masuk dalam kategori "sangat layak". Dari ketiga uji yang sudah dilakukan maka panduan sinema edukasi dengan model blended learning untuk menurunkan tingkat prokrastinasi akademik "sangat layak" digunakan sebagai alternatif bagi konselor sekolah dalam pelaksanaan layanan dalam upaya mengurangi tingkat prokrastinasi akademik siswa SMA.

Produk buku panduan ini memiliki keunggulan dan kekurangan. Keunggulan pertama yaitu produk panduan ini menggunakan sinema edukasi. Sinema Edukasi merupakan teknik pembelajaran yang menggunakan media film yang menceritakan sebuah tokoh. Film dapat merubah perilaku dan memberikan dampak signifikan pada individu (Auliyah \& Flurentin, 2016; Njoku, 2016). Selain itu pada prosedur pelaksanaan dilengkapi dengan contoh kalimat instruksi yang dibuat sedemikian rupa untuk membantu memudahkan konselor menggunakan buku panduan. Keterampilan berkomunikasi guru merupakan faktor penting dalam meningkatkan efektifitas pembelajaran (Fitri \& Taufik, 2019). Buku panduan ini menggunakan model blended learning yang menambah keefektifan dalam pelaksanaan layanan. Model blended learning memiliki beberapa keunggulan antara lain: (1) pembelajaran lebih efektif dan efisien; (2) meningkatkan aksesibilitas; (3) siswa memiliki keleluasaan dalam belajar secara mandiri; (4) mampu melengkapi kebutuhan dalam pembelajaran; (5) pembelajaran lebih menarik minat siswa (Husamah, 2015). 
Buku panduan ini dicetak menggunakan kertas glossy pada bagian sampul dan kertas HVS ukuran A4 pada bagian isi. Berdasarkan keunggulan-keunggulan produk panduan sinema edukasi dengan model blended learning ini dapat membantu memudahkan konselor dalam menurunkan tingkat prokrastinasi akademik siswa.

Proses penelitian dan pengembangan panduan ini tidak lepas kendala dan keterbatasan yang ada. Beberapa keterbatasan dalam produk panduan ini. Pertama, panduan sinema edukasi dengan model blended learning untuk menurunkan tingkat prokrastinasi akademik siswa ini masih berupa prototype yang belum diuji kepada siswa secara langsung. Kedua, dalam proses penelitian dan pengembangan ini peneliti hanya melakukan lima tahap dari Borg \& Gall dikarenakan tujuan dari penelitian dan pengembangan ini yaitu menghasilkan panduan dari sisi format dan isi yang teruji aspek kegunaan, kelayakan, dan ketepatan oleh ahli BK, ahli media pembelajaran dan calon pengguna (konselor/guru BK).

\section{Simpulan}

Penelitian dan pengembangan ini menghasilkan panduan ini telah tervalidasi oleh ahli materi, ahli media, dan calon pengguna serta telah memenuhi unsur keberterimaan panduan yakni kegunaan, ketepatan, kemenarikan, dan kemudahan. Keberterimaan pada format ini menunjukkan bahwa panduan ini telah berterima sebagai panduan yang layak digunakan bagi konselor di sekolah. Data deskriptif yang dihasilkan dari kritik dan saran ahli materi, ahli media, serta calon pengguna telah diakumulasi sebagai bahan revisi produk panduan.

\section{Daftar Rujukan}

Abdollahi, A., Maleki Farab, N., Panahipour, S., \& Allen, K. A. (2020). Academic Hardiness as a Moderator between Evaluative Concerns Perfectionism and Academic Procrastination in Students. The Journal of Genetic Psychology, 181(5), 365-374. https://doi.org/10.1080/00221325.2020.1783194

Auliyah, A., \& Flurentin, E. (2016). Efektifitas Penggunaan Media Film untuk Meningkatkan Empati Siswa Kelas VII SMP. Jurnal Kajian Bimbingan dan Konseling, 1(2), 19-26. https://doi.org/10.17977/um001v1i12016p019

Bielawski, L., \& Metcalf, D. S. (2003). Blended elearning: Integrating knowledge, performance, support, and online learning. Human Resource Development.

Borg, W. R., \& Gall, M. D. (1983). Educational Research: An Introduction. New York: Longman Publishing.

Candra, U., Wibowo, M. E., \& Setyowani, N. (2014). Faktor-Faktor Penyebab Prokrastinasi Akademik pada Siswa Kelas XI SMA Negeri Kabupaten Temanggung. Indonesian Journal of Guidance and Counseling: Theory and Application, 3(3), 66-72.

Febriani, R. O., \& Erfantinni, I. H. (2020). Hybrid Active Learning untuk Menurunkan Prokrastinasi Akademik Mahasiswa Pendidikan Guru Madrasah Ibtidaiyah (PGMI). JKTP: Jurnal Kajian Teknologi Pendidikan, 3(4), 388-397.

Fitri, N., \& Taufik, T. (2019). Relationship between the Atmosphere of Interpersonal Communication between Teacher and Students with Student Learning Activeness. Jurnal Neo Konseling, 1(3).

Ghufron, M. N., \& Suminta, R. R. (2010). Teori-teori psikologi.

Gregory, R. J. (2011). Validity and test development. Psychological Testing; History, Principles and Applications 6th Ed. Boston: Allyn \& Bacon, 109-151.

Guo, M., Yin, X., Wang, C., Nie, L., \& Wang, G. (2019). Emotional intelligence a academic procrastination among junior college nursing students. Journal of Advanced Nursing, 75(11), 2710-2718. https://doi.org/10.1111/jan.14101

Hen, M., \& Goroshit, M. (2020). The effects of decisional and academic procrastination on students' feelings toward academic procrastination. Current Psychology, 39(2), 556-563. https://doi.org/10.1007/s12144-017-9777-3 
Husamah, H. (2015). Blended project based learning: Metacognitive awareness of biology education new students. Journal of Education and Learning (EduLearn), 9(4), 274-281.

Lukitasari, E. (2017). Pengembangan media komik bimbingan dan konseling tentang prokrastinasi akademik bagi siswa di SMK Negeri 2 Sewon. Jurnal Riset Mahasiswa Bimbingan Dan Konseling, 3(8), 396-405.

Munawaroh, M., Alhadi, S., \& Saputra, W. (2017). Tingkat Prokrastinasi Akademik Siswa Sekolah Menengah Pertama Muhammadiyah 9 Yogyakarta. Jurnal Kajian Bimbingan Dan Konseling, 2(1), 26-31. https://doi.org/10.17977/um001v2i12017p026

Njoku, N. C. (2016). Impact of Nigerian Home Video/Movie Industry on the Moral Behaviours of Secondary School Students in Ebonyi State of Nigeria. Journal of Education and Practice, 7(26), 182-186.

Puspita, A., \& Fatchurahman, M. (2018). Pelaksanaan Layanan Bimbingan Kelompok Untuk Meningkatkan Disiplin Belajar Peserta Didik. Suluh: Jurnal Bimbingan dan Konseling, 3(2), 1-11.

Ragil, E., Ariyanto, R. D., Ratnawati, V., Ningsih, R., \& Valdino, D. R. (2019). Keefektifan Teknik Modeling Berbasis Sinema Edukasi untuk Meningkatkan Efikasi Diri Akademik Siswa SMP. Jurnal Nusantara of Research, 6(1), 50-59.

Ramadhan, R. P., \& Winata, H. (2016). Prokrastinasi akademik menurunkan prestasi belajar siswa. Jurnal Pendidikan Manajemen Perkantoran (JPManper), 1(1), 154-159.

Sjukur, S. B. (2012). Pengaruh blended learning terhadap motivasi belajar dan hasil belajar siswa di tingkat SMK. Jurnal Pendidikan Vokasi, 2(3).

Steel, P., \& Klingsieck, K. (2015). Procrastination. In J. D. Wright (Ed.), The international encyclopedia of the social \& behavioral sciences (pp. 73-78). Oxford: Elsevier.

Utaminingsih, S., \& Setyabudi, I. (2012). Tipe kepribadian dan prokrastinasi akademik pada siswa SMA " X " tangerang. Jurnal Psikologi Edukasi, 10(1), 48-57.

Yuniarisla, U. (2018). Pengembangan panduan pelatihan manajemen waktu untuk mengurangi prokrastinasi akademik siswa SMP. Universitas Negeri Malang.

Yuslia, M. A. Y., Sofah, R., \& Harlina, H. (2020). Pengaruh layanan bimbingan klasikal dengan menggunakan media film pendek terhadap perilaku prokrastinasi akademik siswa SMP negeri 2 Indralaya Utara. Universitas Sriwijaya. 